\title{
How Close Is Close: 16S rRNA Sequence Identity May Not Be Sufficient To Guarantee Species Identity
}

\author{
GEORGE E. FOX, ${ }^{1 *}$ JEFFREY D. WISOTZKEY, ${ }^{2}$ AND PETER JURTSHUK, JR. ${ }^{2}$ \\ Departments of Biochemical and Biophysical Sciences ${ }^{1}$ and Biology, ${ }^{2}$ \\ University of Houston, Houston, Texas 77204-5934
}

\begin{abstract}
16S rRNA (genes coding for rRNA) sequence comparisons were conducted with the following three

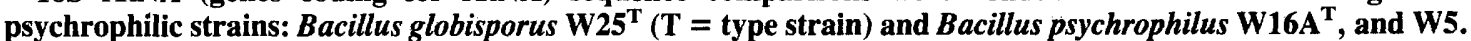
These strains exhibited more than $99.5 \%$ sequence identity and within experimental uncertainty could be regarded as identical. Their close taxonomic relationship was further documented by phenotypic similarities. In contrast, previously published DNA-DNA hybridization results have convincingly established that these strains do not belong to the same species if current standards are used. These results emphasize the important point that effective identity of $16 \mathrm{~S}$ rRNA sequences is not necessarily a sufficient criterion to guarantee species identity. Thus, although 16S rRNA sequences can be used routinely to distinguish and establish relationships between genera and well-resolved species, very recently diverged species may not be recognizable.
\end{abstract}

The genus Bacillus is a large, heterogenous group of gram-positive, aerobic, endospore-forming, rod-shaped bacteria. The phenotypic diversity of the genus has been well documented, and nearly every imaginable phenotype is represented in one species or another $(5,7,8,18,19,23)$. For more than 100 years psychrophilic bacteria have been known to exist (11), but the first true isolate of a psychrophilic Bacillus strain was not described until 1966. As described by Larkin and Stokes $(13,14)$, the psychrophilic Bacillus species, Bacillus psychrophilus, Bacillus globisporus, Bacillus psychrosaccharolyticus, and Bacillus insolitus, are all related phenotypically by the underlying theme that each is capable of growth and sporulation at $0^{\circ} \mathrm{C}$.

The taxonomic relationship of two of these psychrophilic species, $B$. psychrophilus and $\boldsymbol{B}$. globisporus, has been the subject of some debate because phenotypic differentiation between them historically has been difficult $(8,17-19,22$, 24). In an effort to help resolve the taxonomic relationship between $B$. psychrophilus and $B$. globisporus, Ruger and Richter (22), analyzed the previously published phenotypic data and performed cell wall analyses. These authors found virtually no difference between these two species and proposed that $B$. psychrophilus should be considered a subjective synonym of $B$. globisporus. Nakamura (17) felt that $B$ psychrophilus could be phenotypically differentiated from $B$. globisporus on the basis of (i) its smaller cell size, (ii) its ability to grow at $30^{\circ} \mathrm{C}$, (iii) its ability to grow in the presence of $3 \% \mathrm{NaCl}$, (iv) its ability to reduce nitrate to nitrite, and (v) its ability to ferment D-mannitol, D-ribose, trehalose, and D-xylose. On the basis of these observations, it was proposed that the name B. psychrophilus should be revived. As a result, $B$. psychrophilus and $B$. globisporus are currently recognized as separate species $(17,23)$.

Genotypically, there is clear evidence for differentiation of these two organisms. Nakamura reported a level of DNADNA hybridization of $23 \%$ between the type strains (17), while Ruger reported a value of $50 \%$ (21). Although these values are not as consistent as one would expect or like, it is apparent that there is enough genotypic difference to justify two species if the usual criterion is used (26). In order to characterize further the relationship between these two

\footnotetext{
* Corresponding author
}

closely related species, the $16 \mathrm{~S}$ rRNAs (genes coding for rRNA [rDNA]) from $B$. globisporus $\mathrm{W}^{2} 5^{\mathrm{T}}$ ( $\mathrm{T}=$ type strain) and $B$. psychrophilus $\mathrm{W} 16 \mathrm{~A}^{\mathrm{T}}$ and $\mathrm{W} 5$ were sequenced and compared. As reported below, the comparative analysis established that the 16S rRNA sequences of these closely related species are effectively identical. This result provides an important insight into the relationship between 16S rRNA sequence analysis and DNA-DNA hybridization results that must be understood if the two methods are to be utilized in resolving taxonomic problems.

\section{MATERIALS AND METHODS}

Bacterial strains and culture conditions. B. psychrophilus W16A ${ }^{\mathrm{T}}\left(=\right.$ ATCC $22304^{\mathrm{T}}=$ DSM $\left.3^{\mathrm{T}}\right)$ and W5 (= ATCC $23306=$ DSM 2273) and B. globisporus W25 $(=$ ATCC $23301^{\mathrm{T}}=\mathrm{DSM} 4^{\mathrm{T}}$ ) were obtained from John Larkin, Department of Microbiology, Louisiana State University, Baton Rouge. All strains were maintained on Trypticase soy agar (BBL) and were grown at $5^{\circ} \mathrm{C}$. The phenotypic differentiation of our strains of $B$. psychrophilus and B. globisporus was confirmed by using the criteria of Larkin and Stokes (14), Nakamura (17), and Gordon et al. (8).

Amplification and cloning. B. psychrophilus $\mathrm{W} 16 \mathrm{~A}^{\mathrm{T}}$ and W5 and $B$. globisporus $\mathrm{W}^{2} 5^{\mathrm{T}}$ chromosomal DNAs were prepared and polymerase chain reaction (PCR) gene amplifications were carried out as previously described (28). The two primers used were complementary to phylogenetically conserved portions of the $5^{\prime}$ and $3^{\prime}$ ends of the $16 \mathrm{~S}$ rRNAs and contained $5^{\prime}$ restriction site polylinker regions to facilitate cloning. Primer A (5'-CCGAATTCGTCGACAGAGTT TGATCCTGGCTAG- $3^{\prime}$ ) was complementary to the $5^{\prime}$ end of the 16S rRNA gene and contained the restriction sites for EcoRI and SalI, while primer B (5'-CCCGGGATCCAAGCT TAGAAAGGAGGTGATCCA-3') was complementary to the $5^{\prime}$ end of the opposite strand of the 16S rRNA gene and contained restriction sites for SmaI, HindIII, and BamHI. A DNA thermal cycler (Perkin-Elmer-Cetus) was used and programmed as follows: (i) an initial temperature of $94^{\circ} \mathrm{C}$ for 6.5 min was used to melt the double-stranded DNA, (ii) a run of 35 cycles, with each cycle consisting of $1 \mathrm{~min}$ at $94^{\circ} \mathrm{C}, 1$ min at $37^{\circ} \mathrm{C}$, and $3 \mathrm{~min}$ at $72^{\circ} \mathrm{C}$, and (iii) $10 \mathrm{~min}$ at $72^{\circ} \mathrm{C}$ to allow for the extension of any incomplete products. The reaction mixture was held at $4^{\circ} \mathrm{C}$ until it was used. 
The amplification product was purified and digested with appropriate restriction enzymes (2). BamHI and SalI were typically used since EcoRI (9) and $S m a I$ (27a) also cut at conserved internal sites of Bacillus 16S rRNA genes. The digested product was cloned into the sequencing vector M13mp19 and sequenced (15) by using the M13 universal primer and seven internal primers complementary to phylogenetically conserved regions of the 16S rRNA gene. The sequencing primers used were complementary to regions on the Bacillus subtilis 16S rDNA near positions 109, 357, 520, $690,910,1110$, and 1406.

rRNA purification and sequencing. $B$. psychrophilus $\mathrm{W}_{16 \mathrm{~A}^{\mathrm{T}}}$ 16S rRNA was isolated, purified, and sequenced as previously described by using a reverse transcriptase-mediated, primer-directed, dideoxynucleotide chain-terminating sequencing technique (12).

Data analysis. Autoradiographs were read twice by one investigator and reread by another investigator. The sequence data were analyzed with a microVAX II (Digital Equipment Corp.) running the VMS operating system. A locally developed software package based on Olsen's SEQEDT (kindly provided by Gary Olsen, University of Illinois at Urbana-Champaign), which was especially designed for manipulating rRNA sequence data, was used to align the sequences and generate similarity values. Sequences were aligned with the previously published sequence of the $16 \mathrm{~S}$ rRNA from $B$. subtilis (10). Sequences were aligned by using highly conserved regions of sequence and areas of known secondary structure as reference points. All regions of the sequence were unambiguously aligned and hence included in the analysis.

The 16S rRNA (rDNA) sequence of B. psychrophilus W16A ${ }^{\mathrm{T}}$ was determined both by sequencing the rRNA directly via reverse transcriptase and by sequencing the PCR-amplified 16S rRNA gene. As a control for amplification errors and possible sequence differences because of organismic microheterogeneities within the psychrophilic Bacillus species, we repeated (on four separate occasions) the DNA extraction, amplification, cloning, and sequencing steps with a single strain of Bacillus psychrosaccharolyticus and observed no differences (27a).

Nucleotide sequence accession numbers. The nucleotide sequences were deposited in the EMBL data base under the following accession numbers: $B$. psychrophilus $\mathrm{W}_{16 \mathrm{~A}^{\mathrm{T}}}$, X54968; B. psychrophilus W5, X54969; and B. globisporus, X54967.

\section{RESULTS}

Partial 16S rRNA sequences more than 1,000 nucleotides long were determined for $B$. psychrophilus W16A $\mathrm{A}^{\mathrm{T}}(1,458$ bases) and W5 (1,458 bases) and B. globisporus W25 ${ }^{\mathrm{T}}(1,399$ bases) by sequencing the PCR-amplified DNAs. In addition, 1,385 positions of $B$. psychrophilus $\mathrm{W}_{16 \mathrm{~A}^{\mathrm{T}}}$ were examined by direct sequencing of the rRNA, using reverse transcriptase. Although the reverse transcriptase gels contained the usual ambiguities (nonspecific stops, etc.) associated with this technique, no convincing differences were observed between the PCR sequences and the reverse transcriptase data.

The 16S rRNA (rDNA) sequences from $B$. psychrophilus $\mathrm{W} 16 \mathrm{~A}^{\mathrm{T}}$ and $\mathrm{W} 5$ were identical in all but two positions. These differences were located at $B$. subtilis positions 284 and 1265 , which are typically variable. The 16S rRNA (rDNA) from $B$. globisporus (determined by sequencing the PCR-amplified rDNA) differed from that of each of the B. psychrophilus strains in three positions. Two of these changes were unique to $B$. globisporus and occurred in the region from position 997 to position 1044 (Escherichia coli numbering) of the $16 \mathrm{~S}$ rRNA, which is typically quite variable in bacterial species. A DNA probe to distinguish the two species might be fashioned on the basis of these differences. It is possible that there are additional sequence differences in strains $\mathrm{W} 25^{\mathrm{T}}$ and $\mathrm{W} 16 \mathrm{~A}^{\mathrm{T}}$ since the remaining short unsequenced region encompassed one of the more variable sections of the $16 \mathrm{~S}$ rRNA molecule. With the existing data the overall level of sequence identity between $B$. globisporus and either strain of $B$. psychrophilus was $99.8 \%$.

The extremely high level of similarity of these sequences must be considered in the context of possible uncertainties associated with $16 \mathrm{~S}$ rRNA sequencing. These uncertainties include sequencing errors, amplification errors, and the possibility of microheterogeneity that is due to the presence of multiple rRNA cistrons. The magnitudes of these uncertainties are not known precisely but are clearly comparable to the number of differences actually found. Thus, although we are confident that the 16S rRNA sequence differences observed in this study are experimentally meaningful, we nevertheless conclude that in toto they are not statistically significant, and hence these sequences cannot be regarded as significantly different.

Nakamura (17) was able to differentiate the smaller $B$. psychrophilus strains from $B$. globisporus on the basis of cell size and the ability to grow at $30^{\circ} \mathrm{C}$, as well as the ability to grow in the presence of $3 \% \mathrm{NaCl}$. B. psychrophilus also reduced nitrate to nitrite and fermented D-mannitol, D-ribose, trehalose, and D-xylose. From a survey of the literature it is apparent that the phenotypic differentiation of these organisms is difficult. Conflicting data for B. psychrophilus and $B$. globisporus have been reported for the following characteristics: (i) growth in $3 \% \mathrm{NaCl}$, (ii) biochemical reduction of nitrate to nitrite, (iii) ability to ferment D-mannitol, trehalose, D-xylose, and D-glucose, and (iv) ability to hydrolyze starch $(7,14,17,21,22)$. Such discrepencies cast doubt as to whether these traits can be used to differentiate these organisms properly at the phenotypic level. More convincingly, however, the previously reported values for DNA-DNA hybridization between $B$. psychrophilus and $B$. globisporus (23\% [17] and 50\% [21]) are too low for these organisms to be considered members of the same species (5).

The only phenotypic differences that were found to be useful for differentiating $B$. psychrophilus and B. globisporus in our study were (i) the cells of $B$. psychrophilus were slightly smaller and did not stain as darkly with methylene blue as those of $B$. globisporus, (ii) B. psychrophilus grew well at $32^{\circ} \mathrm{C}$, while $B$. globisporus did not grow at temperatures above $30^{\circ} \mathrm{C}$, and (iii) when the organisms were grown on Trypticase soy agar at $22^{\circ} \mathrm{C}$, the colonies of $B$. globisporus appeared to be larger than those of $B$. psychrophilus. Both organisms grew well at 4 and $22^{\circ} \mathrm{C}$, and neither grew at $37^{\circ} \mathrm{C}$. These results are consistent with the previously published phenotypic characterizations of these organisms $(8$, $14,17,21,22)$.

\section{DISCUSSION}

Our results here pose a special problem for bacterial systematics. We studied two strains that can be distinguished phenotypically and exhibit enough genotypic difference that they can be correctly assigned to different species on the basis of current criteria (26). Nevertheless, we are asked to apply a polyphasic approach to taxonomy (16) and 
TABLE 1. Levels of $16 \mathrm{~S}$ rRNA sequence similarity among Bacillus species

\begin{tabular}{|c|c|c|c|c|c|c|c|c|c|c|c|c|c|}
\hline \multirow[b]{2}{*}{ Species } & \multicolumn{12}{|c|}{$\%$ of similarity with: } & \multirow[b]{2}{*}{ Reference } \\
\hline & $\begin{array}{l}\text { B. } \\
\text { alvei }\end{array}$ & $\begin{array}{c}\text { B. } \\
\text { brevis }\end{array}$ & $\begin{array}{c}\text { B. } \\
\text { coagu- } \\
\text { lans }\end{array}$ & $\begin{array}{c}\text { B. } \\
\text { cyclo- } \\
\text { hepatan- } \\
\text { icus }\end{array}$ & $\begin{array}{c}\text { B. } \\
\text { latero- } \\
\text { sporus }\end{array}$ & $\begin{array}{l}B . \\
\text { mac- } \\
\text { erans }\end{array}$ & $\begin{array}{c}B . \\
\text { maquar- } \\
\text { iensis }\end{array}$ & $\begin{array}{c}\text { B. } \\
\text { mari- } \\
\text { nus }\end{array}$ & $\begin{array}{c}B . \\
\text { mega- } \\
\text { terium }\end{array}$ & $\begin{array}{l}\text { B. } \\
\text { poly- } \\
\text { myxa }\end{array}$ & $\begin{array}{c}\text { B. } \\
\text { psychro- } \\
\text { philus }\end{array}$ & $\begin{array}{c}\text { B. } \\
\text { stearo- } \\
\text { thermo- } \\
\text { philus }\end{array}$ & \\
\hline B. alvei & & & & & & & & & & & & & 20 \\
\hline B. brevis & 89.2 & & & & & & & & & & & & $\begin{array}{l}\text { Unpublished } \\
\text { data }\end{array}$ \\
\hline B. coagulans & 88.5 & 88.7 & & & & & & & & & & & 20 \\
\hline B. cycloheptanicus & 86.1 & 82.7 & 84.4 & & & & & & & & & & 28 \\
\hline B. laterosporus & 89.9 & 94.2 & 88.5 & 83.1 & & & & & & & & & 20 \\
\hline B. marcerans & 94.5 & 87.4 & 88.3 & 85.4 & 88.6 & & & & & & & & 20 \\
\hline B. macquariensis & 93.0 & 86.8 & 87.8 & 84.0 & 88.6 & 92.9 & & & & & & & 20 \\
\hline B. marinus & 89.2 & 87.2 & 91.6 & 85.5 & 89.1 & 88.2 & 88.0 & & & & & & $\begin{array}{l}\text { Unpublished } \\
\text { data }\end{array}$ \\
\hline B. megaterium & 89.3 & 87.7 & 92.9 & 84.5 & 89.3 & 88.2 & 88.5 & 93.1 & & & & & 1 \\
\hline B. polymyxa & 93.1 & 86.9 & 87.9 & 84.6 & 87.8 & 93.8 & 92.0 & 88.7 & 87.4 & & & & 20 \\
\hline B. psychrophilus & 89.2 & 87.7 & 90.9 & 84.8 & 87.7 & 88.4 & 87.7 & 93.2 & 91.1 & 87.5 & & & \\
\hline B. stearothermophilus & 88.0 & 88.2 & 90.5 & 85.8 & 88.0 & 87.6 & 86.9 & 90.4 & 91.5 & 86.7 & 89.7 & & 20 \\
\hline B. subtilis & 89.3 & 88.3 & 93.3 & 84.9 & 88.4 & 87.8 & 87.8 & 93.2 & 93.7 & 87.7 & 91.3 & 91.3 & 10 \\
\hline
\end{tabular}

in so doing find that the 16S rRNA sequences of these organisms are not clearly different. What then is to be concluded about these taxa? This is an important issue because 16S rRNA sequence characterization is being widely used in evolutionary, taxonomic, and ecological studies not only to define taxa but also to characterize which taxa are present. In the latter task, two organisms with effectively identical 16S rRNA sequences (i.e., less than 5 to 15 differences) might be assumed to belong to the same species. Thus, if a data base of known 16S rRNA sequences (i.e., type strains) is available, one might expect to be able to identify the organisms present in a medical or ecological sample to the species level without actual culture work. As has been argued by other workers (1) and is clarified below, this is at best approximately true.

In order to evaluate the implications of the B. globisporus$B$. psychrophilus results, an examination of the 16S rRNA sequence literature was undertaken. It is apparent from the results of studies of numerous diverse taxa that the majority of recognized species that have been examined to date differ in their 16S rRNA sequences from related species of the same genus in at least $1.5 \%$ of the sequence positions, and typically more. In the examples shown in Table 1 , wellresolved Bacillus species whose 16S rRNAs have been sequenced typically differ from one another in many more positions than the $B$. psychrophilus- $B$. globisporus pair, whose level of sequence similarity is $99.8 \%$. Indeed, among these Bacillus strains the average species-species pair shares only $88.7 \%$ sequence similarity, while the most similar pair
(Bacillus macerans and Bacillus alvei) exhibits only $94.5 \%$ sequence similarity. Although the species of the genus Bacillus as currently constituted may have to be reallocated to more than one genus (20), it is nevertheless clear that recognized species are typically separated by much greater evolutionary distances than the distance observed for the $B$. psychrophilus-B. globiformis pair. In the context of the genus Bacillus, this conclusion is in fact supported by a larger data set of unpublished $16 \mathrm{~S}$ rRNA sequences (6a). These findings strongly imply that the problem at hand relates more to species definition than to genus definition.

In terms of extremely closely related strains, the key issue is the relationship between $16 \mathrm{~S}$ rRNA sequence similarity and DNA-DNA hybridization results. Only a modest amount of data is presently available (Table 2) that specifically addresses this issue. It is apparent from this data set that when the level of $16 \mathrm{~S}$ rRNA identity is $99 \%$ or more, DNA-DNA hybridization may or may not document the existence of species identity. Clearly, at these levels of sequence similarity the accuracy of the 16S rRNA determination is subject to inherent errors, and small differences cannot necessarily be regarded as significant. What is observed then is that effective identity of $16 \mathrm{~S}$ rRNA sequences does not guarantee species identity as determined by the DNA-DNA hybridization criterion. In contrast, we have not found any instances in which strains that are well resolved by 16S rRNA methods are indistinguishable on the basis of DNA-DNA hybridization results. In a trivial sense these results simply verify what is well known, that $16 \mathrm{~S}$ rRNA

TABLE 2. Relationship between DNA-DNA hybridization results and levels of $16 \mathrm{~S}$ rRNA sequence similarity

\begin{tabular}{|c|c|c|c|}
\hline Organism pair & $\begin{array}{l}\text { \% of DNA-DNA } \\
\text { hybridization }\end{array}$ & $\begin{array}{l}\text { \% of } 16 \mathrm{~S} \text { rRNA } \\
\text { similarity }\end{array}$ & Reference(s) \\
\hline Bacillus psychrophilus-Bacillus globisporus & 23,50 & 99.8 & 17,$21 ;$ this study \\
\hline $\begin{array}{l}\text { Mycobacterium intracellulare serovar } 12-\text { Mycobacterium } \\
\text { intracellulare serovar } 19\end{array}$ & 88 & 100.0 & 3,4 \\
\hline $\begin{array}{l}\text { Mycobacterium intracellulare serovar 12-Mycobacterium } \\
\text { intracellulare serovar } 8\end{array}$ & 49 & 98.5 & 3,4 \\
\hline Serpula innocens B256-Serpula innocens $4 / 71$ & 87 & 99.2 & 25 \\
\hline Serpula hyodysenteriae B78-Serpula innocens B256 & 41 & 99.5 & 25 \\
\hline Serpula hyodysenteriae B78-Serpula innocens $4 / 71$ & 40 & 99.1 & 25 \\
\hline Serpula hyodysenteriae B78-Serpula hyodysenteriae B204 & 93 & 99.9 & 25 \\
\hline
\end{tabular}


sequences are more appropriate for determining inter- and intrageneric relationships. Nevertheless, it would be extremely helpful if these two criteria were interfaced in a consistent way.

Within the context of current nomenclature, a possible solution would be to state that effective identity of $16 \mathrm{~S}$ rRNA sequences implies species identity. Organisms that are related in this way but do not meet the $70 \%$ DNA-DNA hybridization requirement could then be relegated to different subspecies. This would have the advantage that a continuous definition of terminology would exist, and both 16S rRNA sequencing and DNA-DNA hybridization could be used to independently assign strains to appropriate species level taxa. The problem with this is that the $70 \%$ criterion was not arbitrarily selected but rather was based on what seemed to be reasonable levels of genetic variability following extensive characterization of numerous isolates. A 16S rRNA criterion for species definition would simply allow too much genetic variability in at least some cases.

The alternative of claiming that $16 \mathrm{~S}$ rRNA data have no relevance to species definition is also not appropriate. It is very apparent that if two strains have effectively identical 16S rRNA sequences, then they are much more closely related than typical distinct species. In fact, if the $16 \mathrm{~S}$ rRNA sequences are $100 \%$ identical, the strains almost certainly will be shown to be the same species by the DNA-DNA hybridization criterion as well. A problem arises only when a small number of sequence differences are found. In these cases (Table 2), it is not at all certain that DNA-DNA hybridization data make a meaningful distinction. In the absence of definitive DNA-DNA data, strains with effectively identical 16S rRNA sequences are best regarded as belonging to the same "rRNA species complex" or "rRNA superspecies." Such strains can be expected to exhibit considerable levels of DNA-DNA homology (typically at least $30 \%$ ), which need not exceed $70 \%$.

The rRNA species complex characterization would be applied to isolates that have a high probability of belonging to the same species. In such cases the $16 \mathrm{~S}$ rRNA data would be sufficient to identify any strains that were clear outsiders but could never convincingly establish that the remaining genetic diversity was consistent with the existence of only one species. This interpretation has already been recognized and implemented by Collins and coworkers $(1,6,27)$. In recent studies of Lactobacillus lactis (6), Streptococcus parasanguis (27), and Mycobacterium intracellulare (4) strains, less than 10 sequence differences were encountered in each case. Since the strains had been assigned to their respective species on the basis of other criteria, the authors attributed the differences to possible interspecies diversity rather than create a new species. In contrast, studies of Bacillus anthracis, Bacillus cereus, Bacillus mycoides, and Bacillus thuringiensis (1) also revealed less than 10 differences among the various strains examined, but in this case the authors did not propose reassignment of the strains to a single species. In each of these cases $(1,4,6,27$; this study) it could simply be said that the strains that were being investigated belong to a single rRNA species complex. Lest readers draw the wrong conclusion, it should be reemphasized that although 16S rRNA data may not be useful in defining species, such data are nevertheless, in most instances, a powerful tool for determining to which species a strain probably belongs once the relevant species are represented in the 16S rRNA sequence data base.

\section{ACKNOWLEDGMENTS}

We thank John Larkin, Department of Microbiology, Louisiana State University, Baton Rouge, for kindly providing the psychrophilic strains used in this study. We thank Janet L. Siefert for her help in preparing the final drafts of the manuscript. We also are indebted to a number of unnamed reviewers who greatly assisted us in clarifying the ideas presented.

This study was supported by grant BSR-8600448 from the National Science Foundation and by grant NSG-7440 from the National Aeronautics and Space Administration.

\section{REFERENCES}

1. Ash, C., J. A. E. Farrow, M. Dorsch, E. Stackebrandt, and M. D. Collins. 1991. Comparative analysis of Bacillus anthracis, Bacillus cereus, and related species on the basis of reverse transcriptase sequencing of $16 \mathrm{~S}$ rRNA. Int. J. Syst. Bacteriol. 41:343-346.

2. Ausubel, F. M., R. Brent, R. E. Kingston, D. D. Moore, J. A. Smith, J. G. Siedman, and K. Struhl. 1987. Current protocols in molecular biology. John Wiley and Sons, New York.

3. Baess, I. 1983. Deoxyribonucleic acid relationships between different serovars of Mycobacterium avium, Mycobacterium intracellulare and Mycobacterium scrofulaceum. Acta Pathol. Microbiol. Immunol. Scand. Sect. B 91:201-203.

4. Boddinghaus, B., J. Wolters, W. Heikens, and E. C. Bottger 1990. Phylogenetic analysis and identification of different serovars of Mycobacterium intracellulare at the molecular level. FEMS Microbiol. Lett. 70:197-204.

5. Claus, D., and D. Fritz. 1989. Taxonomy of Bacillus, p. 5-26. In C. R. Harwood (ed.), Bacillus. Plenum Press, New York.

6. Collins, M. D., C. Ash, J. A. E. Farrow, S. Wallblanks, and A. M. Williams. 1989. 16S rRNA sequence analysis of lactococci and related taxa. Description of Vagococcus fluvialis gen. nov., sp. nov. J. Appl. Bacteriol. 67:453-460.

6a.Fox, G. E., P. Jurtshuk, Jr., et al. Unpublished data.

7. Gordon, R. E. 1981. One hundred and seven years of the genus Bacillus, p. 1-15. In R. C. W. Berkeley and M. Goodfellow (ed.), The aerobic endospore-forming bacteria: classification and identification. Academic Press, London.

8. Gordon, R. E., W. C. Haynes, and C. H.-N. Pang. 1973. The genus Bacillus. U.S. Department of Agriculture, Handbook no. 427. U.S. Department of Agriculture, Washington, D.C.

9. Gottlieb, P., and R. Rudner. 1985. Restriction site polymorphism of ribonucleic acid gene sets in members of the genus Bacillus. Int. J. Syst. Bacteriol. 35:244-252.

10. Green, C. J., G. C. Stewart, M. A. Hollis, B. S. Vold, and K. F. Bott. 1985. Nucleotide sequence of the Bacillus subtilis RNA operon $r r n B$. Gene. 37:261-266.

11. Herbert, R. A. 1986. The ecology and physiology of psychrophilic microorganisms, p. 1-23. In R. A. Herbert and G. A. Codd (ed.), Microbes in extreme environments. Academic Press, New York.

12. Lane, D. J., B. Pace, G. J. Olsen, D. A. Stahl, M. L. Sogin, and N. R. Pace. 1985. Rapid determination of 16 S ribosomal RNA sequences for phylogenetic analyses. Proc. Natl. Acad. Sci. USA 82:6955-6959.

13. Larkin, J. M., and J. L. Stokes. 1966. Isolation of psychrophilic species of Bacillus. J. Bacteriol. 91:1667-1671.

14. Larkin, J. M., and J. L. Stokes. 1967. Taxonomy of psychrophilic strains of Bacillus. J. Bacteriol. 94:889-895.

15. Messing, J., and J. Vieira. 1982. A new pair of M13 vectors for selecting either strand of double-digest restriction fragments. Gene 19:269-276.

16. Murray, R. G. E., D. J. Brenner, R. R. Colwell, P. DeVos, M. Goodfellow, P. A. D. Grimont, N. Pfennig, E. Stacklebrandt, and G. A. Zavarzin. 1990. Report of the Ad Hoc Committee on Approaches to Taxonomy Within the Proteobacteria. Int. J. Syst. Bacteriol. 40:213-215.

17. Nakamura, L. K. 1984. Bacillus psychrophilus sp. nov., nom. rev. Int. J. Syst. Bacteriol. 34:121-123.

18. Priest, F. G., M. Goodfellow, and C. Todd. 1981. The genus Bacillus: a numerical analysis, p. 91-103. In R. C. W. Berkeley and M. Goodfellow (ed.), The aerobic endospore-forming bac- 
teria: classification and identification. Academic Press, London.

19. Priest, F. G., M. Goodfellow, and C. Todd. 1988. A numerical classification of the genus Bacillus. J. Gen. Microbiol. 143:18471882.

20. Rössler, D., W. Ludwig, K. H. Schleifer, C. Lin, T. J. McGill, J. D. Wisotzkey, P. Jurtshuk, Jr., and G. E. Fox. 1991. Phylogenetic diversity in the genus Bacillus as seen by 16S rRNA sequencing studies. Syst. Appl. Microbiol. 14:266-291.

21. Ruger, H. J. 1983. Differentiation of Bacillus globisporus, Bacillus marinus comb. nov., Bacillus aminovorans, and Bacillus insolitus. Int. J. Syst. Bacteriol. 33:157-161.

22. Ruger, H. J., and G. Richter. 1979. Bacillus psychrophilus Larkin and Stokes 1967, a later subjective synonym of Bacillus globisporus Larkin and Stokes 1967. Int. J. Syst. Bacteriol. 29:194-195.

23. Sneath, P. H. A. 1984. Endospore-forming gram-positive rods and cocci, p. 1104-1207. In N. R. Kreig and J. G. Holt (ed.), Bergey's manual of systematic bacteriology, vol. 2. The Williams \& Wilkins Co. Baltimore.

24. Sogin, M. L. 1990. Amplification of ribosomal RNA genes for molecular evolution studies, p. 307-314. In M. A. Innis, D. H. Gelfand, J. J. Sninsky, and T. J. White (ed.), PCR protocols, a guide to methods and applications. Academic Press, San Diego. 25. Stanton, T. B., N. S. Jensen, T. A. Casey, L. A. Tordoff, R. E. Dewhirst, and B. J. Paster. 1991. Reclassification of Treponema hyodysenteriae and Treponema innocens in a new genus, Serpula, as Serpula hyodysenteriae comb. nov. and Serpula innocens comb, nov. Int. J. Syst. Bacteriol. 41:50-58.

26. Wayne, L. G., D. J. Brenner, R. R. Colwell, P. A. D. Grimont, O. Kandler, M. I. Krichevsky, L. H. Moore, W. E. C. Moore, R. G. E. Murray, E. Stacklebrandt, M. R. Starr, and H. G. Trüper. 1987. Report of the Ad Hoc Committee on Reconciliation of Approaches to Bacterial Systematics. Int. J. Syst. Bacteriol. 37:463-464.

27. Whiley, R. A., H. Y. Fraser, C. W. I. Douglas, J. M. Hardie, A. M. Williams, and M. D. Collins. 1990. Streptococcus parasanguis sp. nov., an atypical viridans Streptococcus from human clinical specimens. FEMS Microbiol. Lett. 68:115-122.

27a.Wisotzkey, J. D. Unpublished data.

28. Wistozkey, J. D., P. Jurtshuk, Jr., and G. E. Fox. 1990. PCR amplification of $16 \mathrm{~S}$ rDNA from lyophilized cell culture facilitates studies in microbial systematics. Curr. Microbiol. 21:325327. 